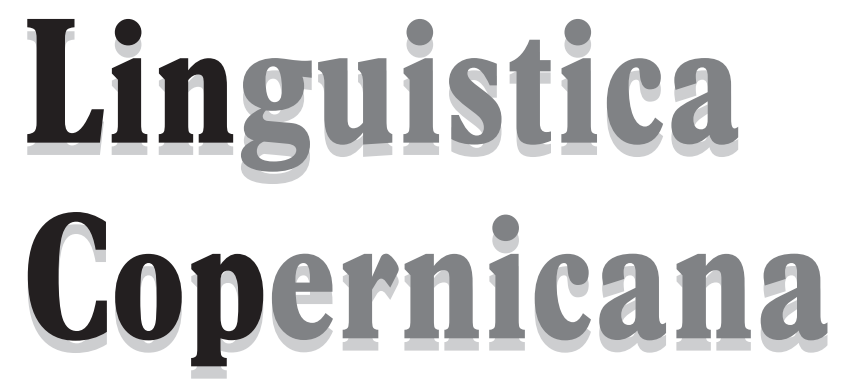

$1(7) / 2012$

WYDAWNICTWO NAUKOWE
UNIWERSytetu MIKOLAJa KOPERNIKA 
REDAKTOR NACZELnY: Maciej Grochowski

Rada Redakcyjna: Ireneusz Bobrowski (Kraków), Andrzej Bogusławski (Warszawa), Gerd Hentschel (Niemcy, Oldenburg), Axel Holvoet (Litwa, Wilno), Krystyna Kleszczowa (Katowice), Roman Laskowski (Kraków), Jarmila Panevová (Czechy, Praha), Jens Nørgård-Sørensen (Dania, Kopenhaga), Zuzanna Topolińska (Macedonia, Skopje), Daniel Weiss (Szwajcaria, Zurich), Anna Wierzbicka (Australia, Canberra)

Kole gi u m R e D K C Y J e: Maciej Grochowski, Krystyna Kallas, Irena Sawicka, Piotr Stalmaszczyk

S E K R ETA R Z R E D A K C I: Iwona Kaproń-Charzyńska

A D R E S R E D A K C J I: Instytut Języka Polskiego UMK, 87-100 Toruń, ul. Fosa Staromiejska 3, e-mail: lincop@umk.pl,www.linguistica.umk.pl

OKŁ A D K A: Monika Pest

(C) Copyright by Wydawnictwo Naukowe Uniwersytetu Mikołaja Kopernika

Toruń 2012

ISSN 2080-1068

Wersją pierwotną (referencyjną) czasopisma jest wersja papierowa.

WYDAWNICTWO NAUKOWE UNIWERSYTETU MIKOEAJA KOPERNIKA

Redakcja: ul. Gagarina 5, 87-100 Toruń

tel. (56) 6114295 , tel./fax 6114705

e-mail: wydawnictwo@umk.pl

Dystrybucja: ul. Reja 25, 87-100 Toruń

tel./fax (56) 61142 38, e-mail: books@umk.pl

www.wydawnictwoumk.pl

Druk: Wydawnictwo Naukowe UMK 


\section{Zbigniew Babik, 2012, \\ Korespondencje akcentowe między stowiańskim i starszymi językami indoeuropejskimi (pierwotne neutra tematyczne). Przyczynki do krytyki akcentologii post-Illicz-Swityczowskiej, Prace Instytutu Filologii Słowiańskiej UJ 27, Kraków: Wydawnictwo Lexis, 557 s.}

Książka dra Babika (który nie wiem, dlaczego do dziś się nie wyhabilitował i nie został profesorem) została napisana w rekordowym czasie 30 miesięcy (XI 2009 - V 2012) i przedstawia się imponująco: liczy ponad 500 stron dużego formatu i wydrukowana jest drobną czcionką, a bibliografia zawiera 1700 pozycji. Wszystko to świadczy o wielkiej erudycji i wielkiej pracowitości Autora. Celem pracy jest krytyka poglądów Illicza-Switycza, który w r. 1963 opublikował słynną książkę o akcentuacji imion w językach bałtyckich i słowiańskich, która to książka stała się źródłem inspiracji dla wielu akcentologów. Celem recenzowanej pracy jest przede wszystkim obalenie tezy Illicza-Switycza o niemal bezwyjątkowym charakterze korespondencji stowiańskie oksytona: barytona staroindyjskie, starogreckie lub pragermańskie w większości imiennych kategorii morfologicznych. A oto garść uwag, jakie mi się nasunęły przy lekturze tej interesującej książki.

Od przeszło 50 lat twierdzę, że we wszystkich językach forma wyrazów zależy od trzech głównych czynników, nie tylko od regularnego rozwoju fonetycznego i rozwoju analogicznego, lecz także od tego, co nazywam nieregularnym rozwojem fonetycznym spowodowanym frekwencją. W trzech monografiach (Mańczak 1969, 1977 i 1987) oraz mnóstwie artykułów przytoczyłem tysiące form, w których moim zdaniem zachodzi związek między nieregularnymi redukcjami fonetycznymi a frekwencją, jednak Z. Babik wszystko to przemilcza z jakiegoś powodu, którego nie ma odwagi ujawnić. Jeśli Autor zna argumenty przemawiające przeciw mojej teorii, to czemuż je trzyma w tajemnicy zamiast je dla dobra nauki ujawnić? A tymczasem, jeśli 
chodzi o „nieregularny rozwój fonetyczny wokalizmu rdzennego” w scs. sъto (s. 187), to trzeba zwrócić uwagę na fakt, że w znacznej większości języków indoeuropejskich liczebniki '20-90' są tworzone podobnie (dwadzieścia, trzydzieści itd. aż do dziewięćdziesięciu, niem. zwanzig, dreißig aż do neunzig, łac. viginti, triginta aż do nonaginta), z czego wniosek, że w praindoeuropejskim liczebnik '100' musiał znaczyć ‘dziesięć dziesiątek' i musiał brzmieć *dek’m dek'motom. Jednak nawet w najwcześniej zaświadczonych językach indoeuropejskich nie zachował się prawidłowy kontynuant wyrażenia praindoeuropejskiego, wszędzie mamy do czynienia z formami nieregularnie skróconymi na skutek częstości użycia. Jeśli chodzi o odnalezienie „w gwarach litew. postaci šum̃tas obocznej do šim̃tas" (s. 188), to w rzeczywistości tłumaczy się ona tak samo jak fakt, że ang. children wymawiane jest nie tylko [čildrən], ale i [čuldrən]. Często używane children w wymowie niektórych Anglików nieregularnie się skróciło do [čldrən], a innym wymówienie tej postaci było zbyt trudne i w ten sposób się pojawiła wymowa [čuldrən]. Mutatis mutandis podobnie się tłumaczy różnica między plur. women [wimin] a sing. woman [wumən] czy fakt, że hol. vriend 'przyjaciel' redukuje się nie tylko do vrind, ale i do vrund (Mańczak 1987: 16 i 25). Tak więc lit. šimtas nieregularnie się skróciło do [šmtas], a niektórym było trudno tę formę wymawiać i zaczęli mówić šumtas. Jeśli chodzi o ,prawa rozwoju wygłosu” (s. 532), to one istnieją jedynie w wyobraźni językoznawców, natomiast w rzeczywistości mamy do czynienia tylko z nieregularnym rozwojem fonetycznym spowodowanym frekwencją (Mańczak 1969a). Rozwój ten nieraz polega na zrastaniu się dwu wyrazów w jeden (co stanowi redukcję, gdyż w miejsce dwu akcentów pojawia się jeden oraz znika pauza między słowami). Na s. 242 Autor mówi o „częstym przerzucaniu akcentu na przyimek w wyrażeniu nadvor w s.-ch., ros., bułg." W rzeczywistości chodzi tu o zrastanie się wyrazów, co zaszło także w pol. 'na "dwór > 'na dwór, choć nie odzwierciedla tego konserwatywna pisownia. Także frekwencją tłumaczy się kajkawskie večêr 'wieczorem' < *vvečer (s. 420). Na s. 150 Autor pisze, że „w tej miejscowości tej zmianie podlega nawet $e \mathrm{w}$ negacji nie przed nazalnymi $n, m$ w nagłosie negowanego wyrazu". Autor nie zdaje sobie sprawy z tego, że w scs. negacja była osobnym wyrazem (por. szóste przykazanie ne prěljuby ştvoriši), natomiast $\mathrm{w}$ polskim nie na skutek częstego użycia zrosło się $\mathrm{z}$ czasownikiem w jeden wyraz, o czym świadczy akcent stale na przedostatniej sylabie (wbrew konserwatywnej pisowni): 'nie mam, 'nie masz, 'nie ma, nie 'mamy itd. 
Na s. 187 czytamy: „Nie analizowaliśmy form liczebników '200(-400)', również pokazujących podobną dezakcentuację nazwy 'setki' (s.-ch. dvjësto itp.)”. Nie wiem, jak jest w serbochorwackim, ale w polskim zasługuje na uwagę, że w częściej używanych niższych liczebnikach powstały zrosty, natomiast w rzadziej używanych wyższych liczebnikach do zrostów nie doszło: ' $d$ wieście, 'trzysta, ale "cztery'sta, "siedem'set, "osiem'set, "dziewięć'set. Na s. 331 czytamy: „Niezrozumiałe i wymagające specjalnych objaśnień jest występowanie w różnych językach połączenie [sic] z przyimkiem *jbz nie rządzącym wyraźnymi formami dopełniacza: możemy tu dopatrywać się nieregularnej apokopy końcówki genetivu, ze słe. por. izvën". Ależ to nie jest żaden problem, tu chodzi całkiem po prostu o nieregularny rozwój fonetyczny spowodowany frekwencją, którego ogromna większość językoznawców z jakichś irracjonalnych pobudek nie chce dostrzegać, choć np. w tekstach polskich zachodzi on w ponad 60\% wyrazów (Mańczak 2011). Scs. nevěsta pochodzi nie od *neue-uédh-tā (s. 210), ale od *newo-wedh-tā, a redukcja *owe do $\check{e}$ thumaczy się nieregularnym rozwojem fonetycznym spowodowanym frekwencją (Mańczak 2005). Według Autora (s. 306-307), fakty czeskie (selo 'część wsi [...]' i pol. sioło) uprawdopodobniają także funkcjonowanie wyrazu *selo o znaczeniu 'osada' [...], którego odpowiedniki bałt. i germ. [...] sugerują wyjściowy wokalizm rdzenny *a, zapewne i tu wtórnie zmieniony pod wpływem bliskoznacznego [...] *sedlo". Moim zdaniem sioło powstało ze skrócenia siodło na skutek częstego użycia. Jako paralelę można przytoczyć rum. sat 'wieś' < łac. fossatum. Według Autora (s. 432), ,pochylenie ó w ustalonym kvóli sięga aż w widły Wisły i Sanu”. Nieregularny rozwój fonetyczny spowodowany frekwencją nieraz polega na redukcji stopnia otwarcia samogłoski. Na s. 66 jest wymienione lit. „pusiaũ $\sim$ pusiáu (z nieregularnym zanikiem końcowego *-s?)”. Słowo 'pół' w różnych językach wykazuje nieregularne redukcje spowodowane częstym użyciem (Mańczak 1996). Na s. 57 Autor poświęca sporo miejsca formie doma. Nie ulega najmniejszej wątpliwości, że forma ta pochodzi od formy loc. sg. *domōun, która doznała nieregularnej redukcji na skutek częstego użycia (Mańczak 1977: 58-60). Na s. 404-405 Autor zajmuje się końcówką acc. sg. *-om, która w masculinach przeszła w scs. $-b$, a w neutrach $\mathrm{w}-o$. Obie końcówki są nieprawidłowe, a to, że w masculinach redukcja jest zaawansowana bardziej niż w neutrach, tłumaczy się tym, że masculina są używane częściej od neutrów. Na s. $405 \mathrm{Au}-$ tor wspomina o dialektach rosyjskich, „które zachowały dawną końcówkę 
nom. sg. jako -e (dialekt staronowogrodzki [...])". Formy na -e i -o wykazują regularny rozwój fonetyczny (Mańczak 2003 i 2003a). Na s. 286 czytamy: „Postać pierwotnego converbium *po [...] podlegała aferezie, nieregularnej zmianie stosunkowo częstej w tego typu wyrazach «funkcyjnych»." W rzeczywistości nieregularnych redukcji doznają nie tylko wyrazy „funkcyjne”, ale i „niefunkcyjne”, byle by tylko były bardzo często używane. Na s. $57 \mathrm{Au}$ tor mówi o końcówce abl. sg. , ${ }^{*}-\bar{o} d>*_{-} \bar{o}$ : litew. -o (nieobjaśnione, zamiast oczekiwanego $† u o)$ ". Końcówka litewska uległa nieregularnej redukcji na skutek częstego użycia. To samo się odnosi do innych końcówek: końcówka 1 os. sg. ${ }^{*}-\bar{o}$ (s. 56), gen. pl. ${ }^{*}-\bar{o} m>-$ - (s. 58), acc. pl. ${ }^{*}-\bar{o} n s>-y$ (s. 59), instr. pl. *-öis $>-y$ (s. 59), acc. pl. *-ās (s. 66), końcówka instr. sg. ,z wczesną w zachsłow. dyspalatalizacją końcowego jeru miękkiego w twardy" (s. 128), „skrócenie w instr. sg. jest może konsekwencją pierwotnej trójsylabowości tej formy i jej oksytonezy marginalnej" (s. 462). Co do tych końcówek zob. Mańczak 1999. Wreszcie należy podkreślić, że według obliczeń pewnego profesora matematyki stosowanej szansa, żeby moja teoria nieregularnego rozwoju fonetycznego spowodowanego frekwencją była błędna, jest mniejsza niż 1 na 10 milionów (Mańczak 2011a). To, że mimo tej opinii wielu językoznawców mojej teorii nadal nie uznaje, tłumaczy się albo kompletną ignorancją w zakresie statystyki, albo złą wolą.

Ponieważ Autor nieraz wspomina o teorii laryngalnej, trzeba wyraźnie stwierdzić, że ona jest nieprawdziwa (Mańczak 2008: 73-85).

W związku z tym, że Autor (s. 14) pisze, iż Kuryłowicz posługiwał się „koncepcjami metodologicznymi trudnymi lub niemożliwymi do zaakceptowania dla pokoleń językoznawczów historycznoporównawczych (por. zwłaszcza Aitzetmüller 1962)”, pragnę zauważyć, że ja już wcześniej zwracałem uwagę na to, że prawa rozwoju analogicznego, na których Kuryłowicz oparł swą L'accentuation des langues indo-européennes, były błędne (Mańczak 1958 i 1960). Fakt, że Z. Babik przemilcza te moje prace, jest dla mnie tym bardziej przykry, że ja za to, że się ośmieliłem skrytykować koncepcję Kuryłowicza, musiałem zapłacić wysoką cenę: przez lata nie mogłem ani wyjeżdżać za granicę, ani awansować (nie mówiąc już o takich drobiazgach jak to, że na zjeździe Polskiego Towarzystwa Językoznawczego rusycysta Mirowicz zażądał usunięcia mnie z Towarzystwa).

W naukach przyrodniczych prawami nazywa się tylko stwierdzenia ważne wszędzie i zawsze. Uważam, że językoznawcy powinni postępować po- 
dobnie określając mianem praw jedynie stwierdzenia dotyczące wszystkich języków i wszystkich okresów ich dziejów, natomiast stwierdzenia odnoszące się do poszczególnych języków powinni nazywać regułami, a więc np. prawo Zipfa, ale reguła Vernera, gdyż reguła Vernera dotyczy tylko jednego języka, a mianowicie pragermańskiego. Autor (podobnie jak znaczna większość językoznawców) nadużywa terminu „prawo”, mówiąc np. o „prawie Saussure'a".

Gdzieś widziałem wzmiankę o ,grupie lechickiej”, natomiast moim zdaniem języków lechickich nigdy nie było (Mańczak 2002).

$\mathrm{Z}$ tego, co Autor pisze na s. 36, można wnosić, że on sądzi, że niegdyś w polszczyźnie był akcent inicjalny. Moim zdaniem nigdy go nie było (Mańczak 1998).

Na s. 97 jest wzmianka o ,germ. *máisaz”. Moim zdaniem wyrazy pragermańskie były zakończone nie na -z, ale na -s (Mańczak 1996a).

Nie nasiono (s. 247), ale nasienie. Niem. nie päßt (s. 244), ale paßt. Łac. nie neutrum, neutri (s. 557), ale neutrius, a $s$. v. to nie sub verbo (s. 557), ale sub voce.

A teraz przechodzę do sprawy najważniejszej. Moim zdaniem wszystkie problemy językoznawcze dzielą się na dwie kategorie, te, które można rozstrzygnąc za pomocą statystyki, oraz te, których za pomocą statystyki rozstrzygnąć się nie da. Oto przykład. W roku 1925 włoski romanista Bartoli doszedł do wniosku, że obszary peryferyczne są bardziej archaiczne od obszarów centralnych, i pogląd ten do dziś jest niemal powszechnie uważany za słuszny. Statystyka jednak przeczy temu poglądowi. Wystarczy porównać fragment Wulgaty z jej przekładami na hiszpański, włoski, rumuński, by się przekonać, że jest więcej zgodności leksykalnych między łaciną a centralnym językiem włoskim niż między łaciną a językami peryferycznymi, jakimi są hiszpański i rumuński (Mańczak 1996b: 178-182). Inny przykład. Według poglądu, który powstał wśród stoików w III w. przed Chr. różnica między nazwami własnymi a rzeczownikami pospolitymi polega na tym, że nazwy własne mają charakter indywidualny, oznaczają pojedyncze desygnaty, podczas gdy rzeczowniki pospolite odnoszą się do wielu desygnatów. Jednak mnóstwo faktów przeczy temu poglądowi, przecież każde imię, każde nazwisko, każda nazwa mieszkańca wsi, miasta, prowincji, kraju czy części świata, tzn. takie nazwy jak Jan, Nowak, krakowianin, Ślazak, Polak czy Europejczyk, oznaczają nie pojedynczych osobników, ale wielu, niekiedy nawet 
miliony ludzi. $Z$ tego powodu powstało kilkanaście jeszcze innych poglądów na istotę nazw własnych. Zapoznawszy się z nimi wszystkimi, doszedłem do wniosku, że każdy z nich ma wyjątki. W tym stanie rzeczy trzeba się zadowolić znalezieniem definicji nazw własnych, która by wykazywała najmniejszą ilość wyjątków. Okazało się, że optymalnym rozwiązaniem jest przyjęcie, że różnica między nazwami własnymi a rzeczownikami pospolitymi sprowadza się do tego, że rzeczowniki pospolite w zasadzie tłumaczy się z języka na język, natomiast nazw własnych w zasadzie się nie przekłada, por. pol. miasto, niem. Stadt, ang. town, fr. ville, ale Warszawa, Warschau, Warsaw, Varsovie (Mańczak 1991).

Wracając do recenzowanej książki, trzeba stwierdzić, że poglądy na losy akcentuacji słowiańskiej w okresie przedhistorycznym, są bardzo zróżnicowane, o czym się łatwo można przekonać, biorąc pod uwagę choćby tylko poglądy Kuryłowicza, Illicza-Switycza, Dybo, Kortlandta czy Babika. Który z tych poglądów jest najbliższy prawdy? Choć długo się nad tym zastanawiałem, niestety doszedłem do wniosku, że za pomocą statystyki tej kwestii rozstrzygnąć się nie da. W tym stanie rzeczy radziłbym Autorowi, żeby zaprzestał niesprawdzalnych spekulacji na temat akcentologii, a zajął się etymologią, w której twierdzeń absolutnie pewnych, twierdzeń, co do których wśród etymologów panuje jednomyślność, jest bez porównania więcej niż w akcentologii. Obecnie mamy tylko dwa pełne słowniki etymologiczne języka polskiego. Trzeci taki słownik byłby ze wszech miar pożądany, a do jego napisania Autor z racji swej podziwu godnej erudycji oraz wysokiej wydajności pracy nadawałby się bardziej niż ktokolwiek inny. Warto też podkreślić, że słownik etymologiczny Brücknera jest cytowany setki razy częściej niż L'accentuation des langues indo-européennes Kuryłowicza, której niesprawdzalne wyniki nie wytrzymały próby czasu. Oby Autor poszedł w ślady Brücknera, a nie Kuryłowicza. 


\section{Bibliografia}

MaŃCZAK W., 1958, Tendances générales des changements analogiques, Lingua 7, s. $298-325$ i $387-420$.

- 1960, Odpowiedź Prof. J. Kuryłowiczowi, Biuletyn Polskiego Towarzystwa Językoznawczego 19, s. 191-201.

- 1969, Le développement phonétique des langues romanes et la fréquence, Kraków: Uniwersytet Jagielloński.

- 1969a, Le Problème de «Auslautgesetze» en slave commun, Canadian Slavonic Papers 11, s. 56-65.

- 1977, Stowiańska fonetyka historyczna a frekwencja, Kraków: Uniwersytet Jagielloński.

- 1987, Frequenzbedingter unregelmäßiger Lautwandel in den germanischen Sprachen, Wrocław: Ossolineum.

- 1991, La nature du nom propre. Prolégomènes, Nouvelle Revue d'Onomastique $17-18$, s. 25-28.

- 1996, Staropolskie put 'pół', Język Polski 36, s. 285-288.

- 1996a, La règle de Verner s'applique-t-elle à la position finale?, Historische Sprachforschung 109, s. 110-116.

- 1996b, Problemy językoznawstwa ogólnego, Wrocław: Ossolineum.

- 1998, Czy w polskim był akcent inicjalny?, Rocznik Slawistyczny 51, s. 75-86.

- 1999, Nieregularności w końcówkach staro-cerkiewno-słowiańskich, H. Mieczkowska (red.), In Memoriam Alfredi Zaręba et Josephi Reczek, Kraków: Wydaw. Oddziału Polskiej Akademii Nauk, s. 109-113.

- 2002, O pochodzeniu i dialekcie Kaszubów, Gdańsk: Oficyna Czec.

- 2003, Rzekome refleksy jerów końcowych w gwarach rosyjskich, Slavia Orientalis 52, s. 423-427.

- 2003a, Nieregularny rozwój fonetyczny spowodowany frekwencją w gramotach na korze brzozowej, Slavia Orientalis 52, s. 545-551.

- 2005, Remarques sur la règle de Winter, Acta Linguistica Lithuanica 53, s. 33-37.

- 2008, Linguistique générale et linguistique indo-européenne, Kraków: PAU, Wydz. I Filologiczny, i UJ, Wydz. Filologiczny.

- 2011, Uwagi o słowiańskich słownikach etymologicznych, Rocznik Slawistyczny 60, s. 91-100.

- 2011a, Etymologia przyimka dla a nieregularny rozwój fonetyczny spowodowany frekwencją, Prace Filologiczne 60, s. 189-195.

Witold Mańczak, Kraków, Uniwersytet Jagielloński 
